sciendo Zagreb International Review of Economics \& Business, Vol. 22, Special Conference Issue, pp. 15-23, 2019 (C) 2019 Faculty of Economics and Business, University of Zagreb and De Gruyter Open All rights reserved. Printed in Croatia ISSN 1331-5609; UDC: $33+65$

DOI: 10.2478 /zireb-2019-0002

CONFERENCE PAPER

\title{
Advanced System of SME Financing in Market Economy
}

\author{
Jerzy Różański*
}

\begin{abstract}
Increasing competitiveness of small and medium enterprises, especially in the situation of growing economic globalization in the member countries of European Union and internationalization of activity of such enterprises, requires overcoming numerous obstacles the enterprises have to face. One of the most substantial of them is deficiency of means for the enterprises' growth, particularly the means earmarked for innovative activity. This is mainly the consequence of lack of knowledge about how the enterprises could gain financial means from the alternative financing sources. This hinders establishing the optimal configuration of financing for an enterprise. Consequently, the purpose of the paper to improve enterprises' access to external capital so as to be able to carry out the investments oriented towards strengthening of the enterprises and launching innovative products and services. The main result of research (sample of Polish SME) is preparing of advanced system of financing including alternative forms of financing of SME on each stages of their life cycle, connected with multicriteria forms of their assessment.
\end{abstract}

Keywords: small and medium enterprises; alternative financing sources; financing system of enterprises

JEL Classification: G21, G24, M21

\section{Introduction}

The Member States of the European Union operate in the conditions of increasing globalization and competitiveness. This creates big problems especially for small and medium-sized enterprises operating in these countries, which often struggle for survival or for conditions for further development.

An important factor, co-deciding about further development of these enterprises, is their skillful financing, and in particular the possibility of using, apart from the traditional ones, also alternative sources of financing, such as venture capital funds, business angel funding, hybrid instruments and factoring.

* Jerzy Różański is at Łódź University, Łódź, Poland. 
The aim of the paper is to present proposals for changes in the system of financing small and medium enterprises.

The paper contains an analysis of the results of the research carried out in small and medium-sized enterprises in Poland in 2017. They show that, at all times, small and medium-sized enterprises use a very limited number of financing sources, mainly traditional sources, with the predominance of equity, which is not conducive to the further development of these enterprises.

\section{Sources of Financing for Small and Medium-Sized Enterprises in Poland}

Small and medium enterprises, constituting the overwhelming majority of enterprises operating in countries belonging to the European Union, encounter on the way of their development a number of barriers that they try to overcome with greater or lesser successes. One of the main barriers to the development of small and medium-sized enterprises is one associated with a shortage of financial resources. Small and medium-sized enterprises are a less-attractive capital-receiving partner for external co-financers than large enterprises - usually enjoying a very stable financial situation. It is therefore considered that the financing of small and medium-sized enterprises is associated with increased risk. This reduces the opportunities for these enterprises to raise capital.

Therefore, financial planning in small and medium enterprises must be very precise. It should include:

"1) detailed determination of the capital needs of the company in various phases of its existence; it is necessary to specify in each of these phases the needs for financing the company's fixed assets, and also the need for the working capital (net turnover) of the enterprise,

2) detailed analysis of the possessed financial resources, as it is necessary to assess whether the enterprise is able to finance its needs from its own resources or it is essential to look for new, additional sources,

3) detailed analysis of the sources of financing offered by the market and the immediate surroundings,

4) determining the structure of financing sources, as rational as possible in the given circumstances, taking into account the costs of all sources involved, along with the risks and benefits of selecting different capital kinds, i.e. capital synergy,

5) assessment of selected sources from the point of view of increasing the profitability of the company's functioning and ensuring intensive development, i.e. implementation of the adopted development strategy"(A.Skowronek-Mielczarek, 2003). 
On the other hand, companies will strive to achieve:

- safe capital structure,

- the lowest possible capital costs related to the capital obtained,

- the time of using the capital in line with the needs of the enterprise.

A. Damodaran draws attention to:

"- the continuum between debt and equity,

- internal versus external capital financing,

- the role of cost capital in investment analysis and valuation."(A.Damodaran, 1997)

The literature provides a lot of research on financing the activity of small and medium-sized enterprises. For instance, T. Łuczka and P. Przysiecki make a split into financing current operations of small and medium enterprises and financing investment activity.(T.Łuczka, P.Przysiecki, 2005)

The studies carried out by them in 2005 indicate that the share of foreign capital is increasing gradually. It is the smallest in micro-enterprises (employment up to 9 people), and the largest in medium-sized enterprises (employment from 50 to 249 people).

In micro-enterprises, the share of company's own funds amounted to $73.3 \%$, and in small enterprises to $80 \%$ in financing the current operations.

Bank credits accounted for $13.3 \%$ of financing in micro-enterprises and $10 \%$ of financing in small enterprises.

Medium-sized enterprises used only their own funds in $20 \%$, a combination of company's own funds and bank credit in 40\%, and factoring even in $40 \%$.

The proportions were slightly different in the case of investment activity. As many as $66 \%$ of micro-enterprises and $50 \%$ of small enterprises benefited from internal funds. Apart from that, $10 \%$ of micro-enterprises and $28.7 \%$ of small enterprises used a combination of internal funds and a bank loan. Medium-sized enterprises benefited from their own funds in $27.3 \%$, in $18.3 \%$ from bank loans, and in $36.4 \%$ from a combination of bank loans and the company's own funds.

As for the financing of investment activity, micro-, small and medium enterprises had already benefited from leasing, the more willingly the bigger the enterprise $(2 \%$, $7 \%, 9 \%$, respectively).

Thus, the research conducted in 2005 shows that the basic source of financing, both in the area of current and investment activity, are the company's own funds, followed by a combination of internal funds and a credit.

In the further part of the paper, we will confront the results of these studies with the conclusions from the research conducted in 2017. There are still concerns about the use of foreign capital and if it is used, it involves traditional sources of obtaining foreign capital. Many authors point out the reasons for this state of affairs. 
The factors enumerated by them include:

- lack of access to external sources of financing due to high uncertainty of the activity of the SME sector entities,(B.Mikołajczyk, 2003)

- high capital cost and tightened formal requirements,(A.Ochryniuk, 2003)

- need to demonstrate good financial situation of the company, bureaucracy, time-consuming procedures,(H.Waniak-Michalak, 2007)

- problems with maintaining financial liquidity, which reduces the credibility of the company in the opinion of the capital providers.(A.Pietrzak, 2004)

A. Skowronek-Mielczarek additionally lists factors limiting the development of small and medium enterprises:

- high operating costs of these enterprises and the consequential low level of profitability, which is not conducive to the accumulation of funds,

- limitations related to the legal form of running a business; the dominant form are natural persons conducting business activity, not capital companies that have the widest possibilities of obtaining external financial means, e.g. through the capital market,

- requirement for property collateral, necessary in situations of using specific sources of external financing,

- low level of accumulation capacity of small and medium enterprises, which does not guarantee a return on the invested capital.

In this situation, small and medium-sized enterprises are still trying to base their development on internal financing. As indicated above, in the majority of cases, their own funds are limited, which constitutes a barrier to the rapid development of these enterprises.

Results of the Empirical Research on Financing in Small and Medium Enterprises in the Lodz Region

The survey was conducted under the direction of the author of the paper in 2017 in a group of 429 enterprises from the Lodz region, out of which $61.3 \%$ were micro-enterprises, $30.3 \%$ were small enterprises, and $8.4 \%$ were medium-sized enterprises.

The organizational and legal form of the surveyed enterprises was as follows:

- $51.3 \%$ - enterprises run as a sole proprietorship,

- $11.4 \%$ - civil law partnerships,

- $7.9 \%$ - general partnerships,

- 24.9 - limited liability companies,

- $0.9 \%$ - joint-stock companies.

Using the Likert scale (1-5), the ranking of the criteria validity was determined, which were taken into account during the selection of sources of financing current operations and development in the surveyed enterprises. The average values for individual criteria were as follows:

- cost of obtaining financial resources -4.45 ,

- credibility of financial institution -4.18 , 
- availability of information on a given source of financing - 3.75,

- capacity of funds possible to obtain- 3.74,

- number of documents required to submit - 3.66,

- difficulty getting access to a given source - 3.61,

- deadline for receiving funding - 3.60,

- amount of the one-off installment to be paid -3.58 ,

- recommendation by friends -2.73 .

Thus, the most important criterion determining the selection of the source of financing is the capital cost.

The credibility of the institution financing the enterprise plays a large role, which is probably quite justified.

It is a positive fact that capital recipients take into account many criteria, and therefore they:

- want to have accurate information about the source of funding,

- make the choice of the source of financing dependent on the amount of financial resources needed,

- consider the inconvenience of the procedures accompanying obtaining funds as an important criterion,

- availability of a permanent source of financing,

- short term of receiving funds,

- minimum value of company's own contribution.

On the other hand, as it turns out, informal considerations are of little importance, for example the recommendation of a source of financing by friends.

The sources of financing that were most often chosen by entrepreneurs included:

- credits and loans from banking institutions $-51.5 \%$ of responses,

- leasing $-50.6 \%$ of responses,

- depreciation write-offs $-44.3 \%$ of responses,

- retained profit $-37.8 \%$ of responses,

- aid programs $-36.4 \%$ of responses,

- trade credit $-31.5 \%$ of responses,

- additional payments of partners $-20.7 \%$ of responses,

- acquired from family, friends $-17.7 \%$ of responses.

The most popular sources of financing for small and medium-sized enterprises are therefore credit and leasing, but retained profit and depreciation write-offs, i.e. internal financial sources, also play an important role.

The research also concerned the reasons for not using specific sources of financing that explain why small and medium enterprises did not use certain sources of financing at all.

Data on these reasons and the types of financing that have not been used are included in Table 1. 
Table 1: Reasons for not using specific sources of financing in \%

\begin{tabular}{|c|l|c|c|c|c|c|}
\hline No. & \multicolumn{1}{|c|}{ Source of financing } & $\begin{array}{c}\text { Too high } \\
\text { acquisition } \\
\text { costs }\end{array}$ & $\begin{array}{c}\text { I did not } \\
\text { know this } \\
\text { form }\end{array}$ & $\begin{array}{c}\text { Complicated and } \\
\text { incomprehensible } \\
\text { procedures }\end{array}$ & $\begin{array}{c}\text { Lack of } \\
\text { interest } \\
\text { in this form }\end{array}$ & $\begin{array}{c}\text { No need } \\
\text { to use }\end{array}$ \\
\hline 1 & business angels & 0.90 & 22.00 & 3.50 & 26.90 & 50.50 \\
\hline 2 & venture-capital & 1.40 & 20.50 & 4.20 & 26.90 & 50.90 \\
\hline 3 & forfaiting & 0.70 & 25.70 & 1.90 & 24.50 & 50.00 \\
\hline 4 & depreciation write-offs & 0.80 & 13.00 & 3.80 & 23.00 & 62.30 \\
\hline 5 & factoring & 6.80 & 6.50 & 4.80 & 32.20 & 54.90 \\
\hline 6 & trade credit & 7.80 & 5.80 & 3.70 & 26.20 & 62.90 \\
\hline 7 & issue of shares & 3.30 & 5.40 & 8.00 & 29.20 & 60.80 \\
\hline 8 & issue of bonds & 21.20 & 1.90 & 3.80 & 30.90 & 59.00 \\
\hline 9 & credits and loans & 9.00 & 2.80 & 4.20 & 31.60 & 56.10 \\
\hline 10 & leasing & 2.90 & 8.40 & 27.70 & 20.80 & 45.30 \\
\hline 11 & $\begin{array}{l}\text { aid programs - non-repayable } \\
\text { resources }\end{array}$ & 3.40 & 5.70 & 23.40 & 28.60 & 44.80 \\
\hline 12 & $\begin{array}{l}\text { aid programs - repayable } \\
\text { resources }\end{array}$ & & & & 60.60 \\
\hline
\end{tabular}

Source: elaborated by the Author

The answers provided by the surveyed companies indicate several characteristic phenomena:

- In the case of some forms of financing, high cost of raising the capital constitutes a serious barrier. This applies in the first place to bank credits and loans, but also, although to a lesser extent, to leasing, commercial credits, and factoring.

- One of the most important reasons for avoiding certain forms of financing is the lack of knowledge. This mainly applies to alternative forms of financing, such as financing through business angels, venture capital funds or factoring. It is surprising that depreciation write-offs are not quite known as a form of internal financing. To a lesser extent, there is also noted lack of knowledge concerning aid funds, factoring, trade credit, or issue of shares or bonds. The most known forms - and most often used ones - are loans and leasing.

- As might be guessed, small and medium-sized enterprises have concerns about the use of aid programs, but also in the case of share and bond issues, due to - in their opinion - highly complicated and incomprehensible procedures that accompany the acquisition of funding from these sources. Nevertheless, many alternative forms of financing are not considered to be related to more complicated procedures than most other sources.

- Multiple responses suggested lack of interest or no need to use these sources. This is due to the fact that limiting oneself only to a very narrow group of financing sources results in the lack of interest or the need to use other sources. 
This one-sidedness and a small number of used financing sources are characteristic for small and medium-sized enterprises and may constitute a serious barrier to their further development.

One of the crucial elements of the conducted research was the identification of the most significant problems encountered by enterprises in the course of their efforts to finance their activity. These problems include:

- too high requirements towards the applicant $-79.7 \%$ of responses,

- a very large number of documents to fill in $-71.9 \%$ of responses,

- incomprehensible language of documents $-37.3 \%$ of responses,

- no information provided to the applicant $-29.4 \%$ of responses,

- no people who would help in completing and correcting the application - 26.8\% of responses,

- no offer $-2.6 \%$ of responses,

- a long waiting time for a decision $-2.0 \%$ of responses.

The difficulties are largely formal and therefore ones that could be easily eliminated, so it is even more unfortunate that these problems occur and hinder the acquisition of external capital by small and medium-sized enterprises.

The acquired funds were most often spent on the purchase of fixed assets and current assets.

The distribution of responses was as follows:

- expenses for the purchase, lease, construction or renovation of machinery and equipment, buildings, fixed assets, cars or land $-66.0 \%$,

- current expenditure (for example, purchase of materials) - $61.1 \%$,

- establishing the company - 33.6\%,

- employment, training or additional training of personnel $-18.9 \%$,

- investments in the development of the offer, new products $-2.8 \%$,

- purchase of new technologies (know-how), specialist software, introduction of innovations $-1.9 \%$,

- increase in the working capital $-1.2 \%$,

- patent fees $-0.2 \%$,

- purchase of start-ups $-0.2 \%$.

The above-mentioned answers clearly indicate that the basic financing objectives are investment objectives or goals related to covering current expenses of company's operations. What is noteworthy is the relatively high percentage of responses associated with employment and employee training.

Other expenses - unfortunately including the expenditures on new products or new technologies - were entirely marginal. Small and medium-sized enterprises focus on the basic expenses that determine the survival or development of the company.

On the other hand, a positive result of the conducted research is the declaration on the part of the entrepreneurs that in the future they intend to use foreign funding to the greatest extent. 
The distribution of the responses was as follows:

- foreign financing - $75.2 \%$ of responses (including leasing $-69.7 \%$ of responses, bank loans and bank loans - 68\%, non-repayable aid funds - 55.6\%),

- company's own external financing - $4.6 \%$ of responses (issue of shares - $0.6 \%$ of responses, venture capital $-1.1 \%$, issue of bonds and forfaiting - 1.7\%),

- company's own internal financing - $20.2 \%$ of responses (most frequently depreciation write-offs $-41.6 \%$ of responses).

In the future, the acquisition of capital by small and medium enterprises will be associated with traditional sources of foreign capital. However, it may happen that foreign capital will be used to a greater extent than before.

\section{Proposals for the Financing System for Small and Medium Enterprises}

The research results indicate that there are significant barriers to the financing of small and medium-sized enterprises. These are predominantly:

- no information about many potential sources of financing,

- cumbersome procedures accompanying financing,

- too high requirements for the applicant,

- lack of help from outside in obtaining financing,

- a long waiting time for the decision concerning financing.

In order to overcome these barriers, it is necessary to create a system in which the role of regional authorities in creating conditions for better development and competitiveness of small and medium-sized enterprises operating in a given area will be increased. This can be achieved through:

- Establishment of a support system at the regional level, using non-repayable and repayable aid funds at the disposal of regional authorities, however, closely related to the modern multi-criteria system for assessing the effectiveness of enterprises, determining the granting of these funds.

- Establishment of a team of financial and investment advisers whose task would be to support enterprises in the selection of forms of financing, depending on the scale and type of financial needs related to their development.

- Conducting training and information campaigns aimed at increasing the knowledge of enterprises about possible sources of financing, especially those less known, namely - above all - alternative sources of financing.

It should be remembered that each enterprise has its specific nature of operations, development plans and financing needs related to it. Therefore, it is not possible to create one model of financing for small and medium-sized enterprises. Each enterprise must have its own financing model developed, taking into account also the development phase in which it is located. The combination of financing sources in 
an enterprise that has just started its activity will be different from the set of sources for the company in the development phase, and yet another will be the best for the enterprise in the maturity phase.

Close attention must be paid to the fact that enterprises do not become excessively dependent on a very limited number of funding sources, and therefore on specific capital providers.

Therefore, the best solution is to create for each company such combination of traditional and alternative sources of financing that will allow for the following to happen:

- obtaining a relatively low average weighted capital cost,

- the capital structure will ensure a secure relationship between equity and foreign capital,

- the variety of financing sources will ensure the rapid development of the enterprise.

\section{REFERENCES}

Damodaran, A. (1997). Corporate Finance. New York: John Wiley\&Sons

Łuczka, T., Przysiecki, P.( 2005). Sylwetka mikro i makro przedsiębiorstw w Polsce. In (ed.) A. Bielawska, Uwarunkowania rynkowe rozwoju mikro i małych przedsiębiorstw (pp.136), Szczecin, WNUSz,

Mikołajczyk, B. (2003). Wybrane fazy finansowania małych i średnich przedsiębiorstw w UE. In Finanse i bankowość w integrującej się UE. (eds.) Famulska, T. Nowakowski,J. (pp ...) J.Difin, Warszawawa

Ochryniuk, A. Kredyt we wspieraniu działalności inwestycyjnej przedsiębiorstw. In Banki a rozwój przedsiębiorstwa. (ed.) Sikorski, J. (pp...)Pub. UB, Białystok

Pietrzak, A. (2004). Polityka rządu wobec sektora MSP. In Finanse małych i średnich przedsiębiorstw. (ed.) Pluta, W. (pp. ), PWE, Warszawa 2004,

Skowronek-Mielczarek, A. (2003). Wybory źródeł finansowania w małych i średnich przedsiębiorstwach. In Finansowe aspekty funkcjonowania małych i średnich przedsiębiorstw. (ed.) Orechwa-Maliszewska, E. Kopczuk, A. (pp. 83). Pub. WSFiZ, Białystok

Waniak-Michalak, H. (2007). Pozabankowe źródła finansowania małych i średnich przedsiębiorstw. Wolters-Kluwer, Kraków 